\author{
Jakub Ryśnik \\ https://orcid.org/0000-0001-5994-2922 \\ The Jerzy Kukuczka Academy of Physical Education in Katowice \\ Faculty of Physical Education \\ Department of Health Related Physical Activity and Tourism \\ j.rysnik@awf.katowice.pl
}

\title{
IDENTIFICATION AND EVALUATION OF FACTORS INFLUENCING SPORTS FAN ATTENDANCE AT INTERNATIONAL EVENTS: VOLLEYBALL CASE STUDY
}

\begin{abstract}
The article presents unpublished results of research conducted among fans at the 2014 FIVB Volleyball Men's World Championship (1618 respondents to a direct questionnaire survey). Its aim is to describe selected motives and barriers to attendance at international sports events. The analysis attempts to obtain information about the importance of particular factors and barriers for respondents, their relative importance and to derive a model from the correlation between these variables to explain the attendance of fans at international sports events.
\end{abstract}

Keywords: sport and tourism demand, motives and barriers, sports tourism, international sporting events, sports fans.

\section{INTRODUCTION}

Sports tourism is one of the most dynamically developing types of travel, especially in the form of trips to international sporting events (Kazimierczak, MalchrowiczMośko, 2013; Standeven, DeKnop, 1999). Hadzik (2014) points to the need to explain the theoretical background as it seems to be lagging behind the development of practice in this field.

An important issue is knowledge of demand conditions ${ }^{1}$ as this determines the effectiveness of those managing the offer for consumers. It is particularly desirable to conduct a survey of consumer needs and preferences (Kaczmarek, Stasiak, Włodarczyk, 2010; Kramer, 1997).

This trend includes getting to know the conditions for attendance at international sporting events for consumers. The aim of the article is to present unpublished results of exploratory research conducted among fans of the men's World Volleyball Championships in 2014 (1618 respondents to a direct questionnaire survey) and investigate the hierarchy of importance and internal correlations between factors influencing attendance in the form of motives and barriers, and to search for significant correlations between particular factors and the demographic variables of the studied fans.

\section{LITERATURE REVIEW}

The factors influencing sports tourism are complex. In the literature there are many lists of the factors influencing attendance at major sporting events. Klisiński (2011) distinguishes environmental and personal factors analogous to external and internal conditions (Pilarczyk, Mruk, 2006). Internal (personal) factors include needs, motives, perception, attitudes, personality and learning. On the other hand, external (environmental) conditions include economic factors (income, prices) and socio-cultural (family, reference groups, opinion leaders, social group, culture).

Pitts \& Stotlar (2002) describing the motives of those attending sporting events distinguish several factors:

- socio-demographic (gender, age, education, income, distance from venue),

- economic (ticket price, TV broadcasts, other available leisure activities),

- sport (participation of 'stars', team's style of play (offensive or defensive), the level of competition, the stake, promotion, announcements),

- perceptual (day of the week, weather conditions, number of spectators, violence during games).

There is a current of research in the literature, based on Maslow's model of human needs, aimed at finding 
Table 1. Models of sports event attendance factors

\begin{tabular}{|c|c|c|}
\hline Authors & Factors & Psychometric scale \\
\hline Sloan (1989) & $\begin{array}{l}\text { Health effects, eustress and stimulation, catharsis and aggression, entertainment and } \\
\text { achievements }\end{array}$ & - \\
\hline $\begin{array}{l}\text { Milne, McDonald } \\
\text { (1999) in: Won, } \\
\text { Kitamura (2007) }\end{array}$ & $\begin{array}{l}\text { Stress release, skill mastery, aesthetics, self-esteem, self-actualization, value develop- } \\
\text { ment, social facilitation, affiliation, achievement, risk-taking, aggression, and competition }\end{array}$ & $\begin{array}{l}\text { MSC - Motivations of } \\
\text { the Sport Consumer) }\end{array}$ \\
\hline $\begin{array}{l}\text { Wann, Schrader, } \\
\text { Wilson (1999) in: } \\
\text { Hadzik (2016) }\end{array}$ & $\begin{array}{l}\text { (1) Motive related to the need to spend free time with family and relatives, (2) theme } \\
\text { based on the stimulation of the so-called positive stress (eustress) - cheering stimulates } \\
\text { action and is a source of entertainment and pleasure, (3) motive associated with the } \\
\text { need to belong - cheering is the space for social contacts, (4) motive based on 'escape' } \\
\text { - passive attendance at sport allows to 'escape' from stress, life problems, boredom } \\
\text { and the monotony of everyday life, (5) motive related to the need to raise the self- } \\
\text { esteem of fans when the team or a sportsman wins, (6) motive based on the need for the } \\
\text { entertainment during leisure time, (7) a theme linked to the need for 'spectacularity' } \\
\text { which can be achieved through attendance at many modern sporting events, partic- } \\
\text { ularly those with a global reach, (8) an economic motive based on the need for bet- } \\
\text { ting at bookmaker for profit }\end{array}$ & $\begin{array}{l}\text { SFMS - Sport Fan } \\
\text { Motivation Scale }\end{array}$ \\
\hline Trail, James (2001) & $\begin{array}{l}\text { Achievement, acquisition of knowledge, aesthetics, drama/eustress, escape, family, } \\
\text { physical attractiveness of participants, the quality of the physical skill of the partici- } \\
\text { pants and social interaction }\end{array}$ & $\begin{array}{l}\text { MSSC - Motivation } \\
\text { Scale for Sport } \\
\text { Consumption }\end{array}$ \\
\hline Neale, Funk (2006) & $\begin{array}{l}\text { Vicarious achievement, player interest, entertainment value, drama and socialisa- } \\
\text { tion }\end{array}$ & $\begin{array}{l}\text { Sport Interest } \\
\text { Inventory }\end{array}$ \\
\hline $\begin{array}{l}\text { Funk, Filo, Beaton, } \\
\text { Pritchard (2009) }\end{array}$ & $\begin{array}{l}\text { Socialisation, performance (effectiveness level), excitement, (stimulation/enthusiasm } \\
\text { level), esteem (sense of achievement level), diversion (level of positive change/escape } \\
\text { from the nuisance of everyday life) }\end{array}$ & $\begin{array}{l}\text { SPEED Model, So- } \\
\text { cialization, Perfor- } \\
\text { mance, Excitement, } \\
\text { Esteem and Diversion }\end{array}$ \\
\hline Kim, Trail (2010) & $\begin{array}{l}\text { Scale consists of many dimensions: } \\
\text { - internal motivators (escape, affiliation, achievements, identification with the team: } \\
\text { its community, coach, level, players, discipline) } \\
\text { - external motivators (aesthetics and dramaturgy, media, advertising) } \\
\text { - internal constraints (lack of knowledge, lack of success, lack of someone to watch } \\
\text { the event with, lack of interest from the others) } \\
\text { - external constraints (parking, location, nuisance, financial costs, alternative forms } \\
\text { of recreation, alternative forms of attendance) }\end{array}$ & $\begin{array}{l}\text { Scale for Motivators } \\
\text { and Constraints of } \\
\text { Sport Consumption } \\
\text { (SMCSC) }\end{array}$ \\
\hline
\end{tabular}

Source: author's compilation.

the best model of sports fan motivation (Waśkowski, 2007, in: Hadzik, Ryśnik, Tomik, 2015) (Table 1).

However, it is pointed out that the usefulness of many of these models is limited due to the difficulty of applying results (Funk, Filo, Beaton, Pritchard, 2009). An analysis of motives explains the core of the marketing product but is less indicative of the desired elements of other levels.

Research approaches such as the SPEED scale (Funk, Filo, Beaton, Pritchard, 2009) or the approach proposed by Kim \& Trail (2010) meet these expectations (Table 1). They combine studies of fan motivation with other behavioural factors. Examples include team identification (Robinson, Trail 2005), buying mementoes (Trail, Anderson, Fink, 2002), attending sports events (Kruger, Saayman, 2012; Trail, Fink, Anderson, 2003), future attendance and loyalty to a team (Fink, Trail, Anderson, 2002), demand for match tickets affecting ticket prices (Kemper, Breuer, 2015; Shapiro, Drayer, 2014).

Travel is an extremely important activity for a fan and it involves a number of incentives for attendance at sporting events. Szczechowicz postulates the explanation of a specific 'common space' formed at the junction of sport and tourism and indicates shortcomings in explaining from a theoretical point of view the relations existing between tourism and sport (Szczechowicz, 2015). For example, the question is asked whether tourism and sport generate certain unique values which manifest themselves in a specific synergistic effect (Weed, 2008, in: Szczechowicz, 2015). This is confirmed, amongst others, by the observations of Weed \& Bull (2004), Smith \& Stewart (2007) and Ryśnik, Żylak \& Tomik (2018) who claim that sport and tourism have a lot in common.

Hadzik (2016) states that attendance at sporting events is also determined by the specific conditions of the tourist attractiveness of the event and the venue. For sports fans, the following elements may be important: the possibility of sightseeing while travelling (e.g. natural attractions, cultural monuments, museums, cultural attractions of a sport and recreational nature), the use of sports and recreation facilities, accessibility to night life, the entertainment offer and attendance at non-sport events (Hadzik, Ryśnik, Tomik, 2015).

Attendance at sporting events also depends on barriers. Economic obstacles are significant (Hadzik, Bartík, 2012; Wojdakowski, 2008) and depend on the necessity of 
Table 2. Models of travel factors influencing attendance at sporting events

\begin{tabular}{|c|c|}
\hline Authors & Factors/barriers \\
\hline Yu (2010) & $\begin{array}{l}\text { Cost and ease of arranging travel plans, interest in professional sports, different cultural ex- } \\
\text { perience, interest in travel, experience of watching live sporting events, and the chance to } \\
\text { see Asian players or famous US players in the games }\end{array}$ \\
\hline Mohan, Thomas (2012) & $\begin{array}{l}\text { Travel decisions are influenced by: } \\
\text { - distance } \\
\text { - the scheduling of matches (e.g., weekends or weekdays) } \\
\text { - time spent travelling } \\
\text { - cost of accommodation } \\
\text { - the cost of transport } \\
\text { - mode of transport }\end{array}$ \\
\hline Fairley (2009) & Means of transport as a way of building group identity \\
\hline Ahn, Lee (2014) & $\begin{array}{l}\text { The home team's record, outcome uncertainty, size, and quality of the stadium, playing } \\
\text { styles }\end{array}$ \\
\hline Surdam (2009) & $\begin{array}{l}\text { Non-price determinants of demand for individual games: the day of the week, quality of the } \\
\text { opposition, and special events }\end{array}$ \\
\hline $\begin{array}{l}\text { Simmons, Popp, McEvoy, Howell } \\
\text { (2018) }\end{array}$ & $\begin{array}{l}\text { Attendance constraints: prior commitments to school and work, beverage costs, poor team } \\
\text { performance, and watching the game on television, time commitment necessary to attend, } \\
\text { lack of interest in football }\end{array}$ \\
\hline Nishio (2014) & $\begin{array}{l}\text { The International Sports Fan Constraints Scale: alternative leisure options, security, the lack } \\
\text { of tourist attractiveness, different culture, companions and distance. }\end{array}$ \\
\hline $\begin{array}{l}\text { Anthony, Kahn, Madison, } \\
\text { Paul,Weinbach (2014) }\end{array}$ & $\begin{array}{l}\text { Winning percentage, weather conditions, local income and population, and individual game } \\
\text { promotion such as fireworks }\end{array}$ \\
\hline
\end{tabular}

Source: author's compilation.

paying for admission, transport, accommodation, meals, as well as additional services such as entertainment. Another obstacle may be the lack of flexibility in managing other resources, such as free time, caused by unfavourable dates (Wojdakowski, 2011).

Examples of research into factors influencing travel for the purpose of sport tourism are presented in Table 2.

The set of variables used in the research described in the article was selected from the presented literature on the basis of three premises: (1) comprehensive study of the impact of combined spaces of sport and tourism, (2) barriers, (3) study of aspects close to the operational level of sports and tourism product managers.

\section{METHOD AND ORGANISATION OF THE SURVEY}

The research was conducted by using the anonymous diagnostic survey method. The research was conducted on fans who were present at the matches of the 2014 men's volleyball World Championships (August and September 2014) at the 'Spodek' sports arena in Katowice. 2 The research was carried out at the time when the fans gathered in the arena prior to the matches and involved the fans filling in the questionnaire by themselves.

The variables used in the study included following features measured on a six-degree scale ('no important fac- tor/important barrier' (0) to 'very important factor/ important barrier' (5)):

- the importance of barriers to attendance at volleyball matches of the national volleyball team

- the importance of the factors of attendance at the volleyball matches of the national team

- the importance of additional recreational and tourist services accompanying the volleyball matches of the national team.

The survey also asked about the demographic, social and economic variables of the respondents, i.e. gender, size of place of residence, age, education, professional status and income. The survey also made it possible to distinguish between domestic and foreign fans (origin).

The following research hypotheses were formulated in order to proceed with the research:

Hypothesis 1: Assessment of the importance of particular factors of attendance in sporting events varies depending on the characteristics of respondents, such as:

- gender

- origin (Poland/foreign).

Hypothesis 2: Assessment of the importance of different factors influencing attendance at sporting events.

Hypothesis 3: Particular assessments of factors influencing attendance at sporting events are correlated with demographic characteristics of respondents, such as age, education, professional status, income, marital status and origin (Polish/foreign).

Hypothesis 4: In analysing multidimensional correlations among the variables constituting the factors influencing attendance at sports events, it is possible to 
distinguish hidden factors using exploratory factor analysis as a method of analysis.

The calculations were performed mainly with the help of SAS Enterprise Guide 6.1., MS Excel 2010 and STATISTICA 13.1.

\section{CHARACTERISTICS OF THE TEST SAMPLE}

The database that was created as a result of the survey includes information from 1618 respondents. This number is greater than the estimated minimum sample size considering the population (with an error of $5 \%$ for a population of about 50,000 fans of this event ${ }^{3}$ and a confidence level of 0.95 , the minimum sample size is 381 respondents) (Steczkowski, 1995).

The majority of the respondents were from Poland (1478/91.34\%). The majority were men (55.98\%) (Table 3)

Table 3. Gender and origin of respondents

\begin{tabular}{|c|c|c|c|c|c|}
\hline & \multicolumn{3}{|c|}{ Gender } & \multirow{2}{*}{ Total } \\
\hline & & No answer & Women & Men & \\
\hline & & Quantity & Quantity & Quantity & Quantity \\
\hline \multirow{2}{*}{ Origin } & Poland & 17 & 642 & 819 & 1,478 \\
\hline & Abroad & 4 & 61 & 75 & 140 \\
\hline Total & & 21 & 703 & 894 & 1,618 \\
\hline
\end{tabular}

Source: author using the SAS package.

Table 4. Number of inhabitants in the place of residence, age, education

\begin{tabular}{|c|c|c|}
\hline \multirow{2}{*}{ Size of domicile } & \multicolumn{2}{|c|}{ Supporters } \\
\hline & number & percentage $(\%)$ \\
\hline Up to 10,000 inhabitants & 327 & 20.85 \\
\hline $11-49,000$ & 367 & 23.41 \\
\hline $50-99,000$ & 499 & 31.82 \\
\hline $100-499,000$ & 286 & 18.24 \\
\hline $500-999,000$ & 69 & 4.40 \\
\hline$>1000000$ & 20 & 1.28 \\
\hline \multicolumn{3}{|c|}{ missing data $=50$} \\
\hline Age & number & percentage $(\%)$ \\
\hline Less than 18 & 219 & 13.82 \\
\hline From 19 to 25 & 652 & 41.14 \\
\hline From 26 to 35 & 405 & 25.55 \\
\hline From 36 to 45 & 185 & 11.67 \\
\hline From 46 to 55 & 89 & 5.62 \\
\hline From 56 to 65 & 28 & 1.77 \\
\hline More than 66 & 7 & 0.44 \\
\hline \multicolumn{3}{|c|}{ missing data $=33$} \\
\hline Education & number & percentage $(\%)$ \\
\hline Primary & 136 & 8.62 \\
\hline Vocational & 146 & 9.25 \\
\hline Secondary & 481 & 30.48 \\
\hline Higher incomplete & 238 & 15.08 \\
\hline Higher & 577 & 36.57 \\
\hline
\end{tabular}

Source: author using the SAS package. and fans living in cities with 50-99,000 inhabitants (Table 3). The most numerous age group are those aged 19-25 and 26-35 (Table 4).

The majority of the respondents had higher education (Table 4). A large number were employed or students (Table 5). The majority were unmarried (Table 5).

Table 5. Occupational and marital status of respondents

\begin{tabular}{|c|c|c|c|c|c|}
\cline { 2 - 6 } \multicolumn{1}{c|}{} & Employed & Unemployed & Retired & Pensioner & Student \\
\hline Quantity & 918 & 233 & 33 & 13 & 509 \\
\hline$(\%)$ & 56.74 & 14.40 & 2.04 & 0.80 & 31.46 \\
\hline & \multicolumn{2}{|c|}{ Single } & Married & Divorced & $\begin{array}{l}\text { Widow/ } \\
\text { widower }\end{array}$ \\
\hline Quantity & \multicolumn{2}{|c|}{1031} & 490 & 32 & 8 \\
\hline$(\%)$ & \multicolumn{2}{|c|}{63.72} & 30.28 & 1.98 & 0.49 \\
\hline
\end{tabular}

Source: author using the SAS package.

\section{RESULTS (STRUCTURAL ANALYSIS)}

The distribution of barriers (Table 6) indicates that cost associated with travelling to an international event and the need to find free time are the most burdensome obstacles. The least important barriers were safety considerations during the trip, the event and the match itself.

By examining the significance of the difference between the mean values for particular barriers, it is possible to rank them in order of importance (Table 7).

Similarly, the importance of a group of variable factors (stimulants) for the attendance of fans in sports events was measured (Table 8) and their obtained hierarchy of importance was analysed (Table 9).

The most important factor within these variables is the willingness to attend the event. The least important factor was prestige.

With regard to the factors determining the importance of an additional tourist offer, the surveyed fans valued especially the chance to attend an additional event (e.g. a concert) as well (Tables 10, 11).

\section{RESULTS - ANALYSIS OF GENDER AND ORIGIN-RELATED DIFFERENCES IN IMPORTANCE ASSESSMENTS}

Table 12 presents the results of an analysis of the significance of difference between the average figures characterizing the distribution of responses by gender.

Table 13 presents the results of an analysis of the significance of differences between figures characterizing the distribution of responses by origin of respondents. 
Table 6. Distribution of responses concerning the importance of barriers

\begin{tabular}{|l|l|c|c|c|c|c|c|}
\hline \multicolumn{1}{|c|}{ Variable } & \multicolumn{1}{|c|}{ Description } & Mean & Sd. Dev. & Mode & N & N omission & Median \\
\hline 3.1. Date & The match timeframe constrains fans & 2.287 & 1.613 & 3 & 1604 & 14 & 3 \\
\hline 3.2. Cost & Travel expenses for volleyball matches & $\mathbf{3 . 0 1 6}$ & 1.490 & 3 & 1606 & 12 & 3 \\
\hline 3.3. Safety & Safety concerns during travel and match & 1.547 & 1.557 & 0 & 1595 & 23 & 1 \\
\hline 3.4. Promotion & Inappropriate promotion of national team matches & 2.031 & 1.693 & 0 & 1598 & 20 & 2 \\
\hline 3.5. Acquisition & Buying tickets for matches & $\mathbf{2 . 7 7 6}$ & 1.644 & 3 & 1596 & 22 & 3 \\
\hline 3.6. Offer & Offer at the matches alone & 2.195 & 1.597 & 3 & 1581 & 37 & 2 \\
\hline 3.7. Time & Lack of free time & $\mathbf{2 . 8 0 1}$ & 1.651 & 4 & 1594 & 24 & 3 \\
\hline 3.8. Other & Other & 1.364 & 1.948 & 0 & 165 & 1453 & 0 \\
\hline
\end{tabular}

Source: author using the SAS package.

Table 7. Importance of barriers

\begin{tabular}{|l|c|c|c|c|c|c|c|}
\cline { 2 - 9 } \multicolumn{1}{c|}{} & 3.2. Cost & 3.7. Time & 3.5. Aquisition & 3.1. Date & 3.6. Offer & 3.4. Promotion & 3.3. Safety \\
\hline Average assesment & 3.02 & 2.80 & 2.78 & 2.29 & 2.20 & 2.03 & 1.55 \\
\hline Position & $\mathbf{1}$ & \multicolumn{2}{|c|}{$\mathbf{2}$} & \multicolumn{2}{c}{$\mathbf{3}$} & $\mathbf{4}$ & $\mathbf{5}$ \\
\hline
\end{tabular}

Source: author using the Statistica package.

Table 8. Distribution of responses concerning attendance factors

\begin{tabular}{|l|l|c|c|c|c|c|c|}
\hline \multicolumn{1}{|c|}{ Variable } & Description & Mean & Std. Dev. & Moda & N & N omissions & Median \\
\hline 7.1.type & Type of competition (e.g. European Championship) & $\mathbf{3 . 8 9 2}$ & 1.340 & 5 & 1,593 & 25 & 4 \\
\hline 7.2. rivalry & Possibility of a close-knit match & 3.875 & 1.179 & 5 & 1,605 & 13 & 4 \\
\hline 7.3. brand & Fame of rival teams & 3.637 & 1.324 & 4 & 1,597 & 21 & 4 \\
\hline 7.4. relax & Relaxation, entertainment & 3.898 & 1.205 & 5 & 1,603 & 15 & 4 \\
\hline 7.5. live & Willingness to watch the match live & $\mathbf{4 . 1 3 9}$ & 1.085 & 5 & 1,604 & 14 & 4 \\
\hline 7.6. prestige & Prestige of being a fan of the national team & 2.988 & 1.687 & 5 & 1,602 & 16 & 3 \\
\hline 7.7. stake & Match stake & 3.305 & 1.440 & 3 & 1,601 & 17 & 3 \\
\hline 7.8. level & Anticipated sports level & 3.636 & 1.162 & 4 & 1,602 & 16 & 4 \\
\hline 7.9. star & Live view of a volleyball star & 3.802 & 1.261 & 5 & 1,599 & 19 & 4 \\
\hline 7.10. family & Opportunity to go to a match with family & 3.788 & 1.228 & 5 & 1,603 & 15 & 4 \\
\hline 7.11. place & Place of competition & 3.557 & 1.355 & 5 & 1,597 & 21 & 4 \\
\hline 7.12. other & Other & 1.440 & 1.939 & 0 & 116 & 1502 & 0 \\
\hline
\end{tabular}

Source: author using the SAS package.

Table 9. Importance of attendance factors

\begin{tabular}{|l|c|c|c|c|c|c|c|c|c|c|c|}
\cline { 2 - 12 } \multicolumn{1}{c|}{} & 7.5. live & 7.1. type & 7.2. rivalry & 7.4. relax & 7.9.star & 7.10. family & 7.3. brand & 7.8. level & 7.11. place & 7.7. stake & 7.6. prestige \\
\hline $\begin{array}{l}\text { Average } \\
\text { assessment }\end{array}$ & 4.14 & 3.89 & 3.87 & 3.90 & 3.80 & 3.79 & 3.64 & 3.64 & 3.56 & 3.30 & 2.99 \\
\hline Position & $\mathbf{1}$ & \multicolumn{4}{|c|}{$\mathbf{2}$} & $\mathbf{3}$ & $\mathbf{4}$ & $\mathbf{5}$ & $\mathbf{6}$ \\
\hline
\end{tabular}

Source: author using the Statistica package.

Table 10. Distribution of variables indicating the importance of an additional tourist offer

\begin{tabular}{|l|l|l|c|c|c|c|c|}
\hline \multicolumn{1}{|c|}{ Variable } & \multicolumn{1}{c|}{ Description } & Mean & Std. Dev. & Moda & N & N omissions & Median \\
\hline 8.1. Recreation, sport & Physical recreation, sport & 2.160 & 1.655 & 0 & 1,521 & 97 & 2 \\
\hline 8.2. Nature & Natural attractions & 2.067 & 1.521 & 3 & 1,601 & 17 & 2 \\
\hline 8.3. Entertainment & Entertainment offer & $\mathbf{2 . 3 5 4}$ & 1.608 & 3 & 1,592 & 26 & 3 \\
\hline 8.4. Culture & Cultural attractions & $\mathbf{2 . 4 2 0}$ & 1.541 & 3 & 1,605 & 13 & 3 \\
\hline 8.5. Parties & Additional events & $\mathbf{2 . 5 9 1}$ & 1.525 & 3 & 1,605 & 13 & 3 \\
\hline 8.6. Other & Other & 1.349 & 1.918 & 0 & 146 & 1,472 & 0 \\
\hline
\end{tabular}

Source: author using the SAS package. 
Table 11. Importance of factors concerning the additional tourist offer

\begin{tabular}{|l|c|c|c|c|c|}
\cline { 2 - 6 } \multicolumn{1}{c|}{} & 8.5. Parties & 8.3. Entertainment & 8.4. Culture & 8.1. Recreation, sport & 8.2. Nature \\
\hline Average assessment & 2.59 & 2.35 & 2.42 & 2.16 & 2.07 \\
\hline The position in the hierarchy & $\mathbf{1}$ & \multicolumn{2}{|c|}{$\mathbf{2}$} & $\mathbf{3}$ & $\mathbf{4}$ \\
\hline
\end{tabular}

Source: author using the STATISTICA package.

Table 12. Assessment of significant differences in relation to gender

\begin{tabular}{|c|c|c|c|c|}
\hline \multirow[b]{2}{*}{ Variable } & \multicolumn{4}{|c|}{ Differentiation based on gender } \\
\hline & Mean for women & Mean for men & $p^{\mathrm{a}}$ & $\begin{array}{c}\text { Interpretation } \\
\text { Barrier/factor more important for }\end{array}$ \\
\hline 3.1. Date & 2.178 & 2.382 & $0.012^{\mathrm{a}}$ & Men \\
\hline 3.2. Cost & 3.109 & 2.960 & $0.040^{\mathrm{a}}$ & Women \\
\hline 3.3. Safety & 1.492 & 1.596 & 0.154 & No significant difference \\
\hline 3.4. Promotion & 1.912 & 2.135 & $0.009^{\mathrm{a}}$ & Men \\
\hline 3.5. Acquisition & 2.722 & 2.834 & 0.180 & No significant difference \\
\hline 3.6. Offer & 2.052 & 2.309 & $0.001^{\mathrm{a}}$ & Men \\
\hline 3.7. Time & 2.617 & 2.948 & $0.000^{\mathrm{a}}$ & Men \\
\hline 3.8. Other & 1.107 & 1.558 & 0.188 & No significant difference \\
\hline 7.1. Type & 3.783 & 3.979 & $0.028^{\mathrm{a}}$ & Men \\
\hline 7.2. Rivalry & 3.790 & 3.938 & $0.045^{\mathrm{a}}$ & Men \\
\hline 7.3. Brand & 3.458 & 3.789 & $1.3214534 \mathrm{E}-6^{\mathrm{a}}$ & Men \\
\hline 7.4. Relax & 3.987 & 3.832 & $0.007^{\mathrm{a}}$ & Women \\
\hline 7.5. Live & 4.264 & 4.037 & $0.000032^{\mathrm{a}}$ & Women \\
\hline 7.6. Prestige & 2.810 & 3.129 & $0.00059^{\mathrm{a}}$ & Women \\
\hline 7.7. Stake & 3.110 & 3.461 & $5.113981 \mathrm{E}-6^{\mathrm{a}}$ & Men \\
\hline 7.8. Level & 3.529 & 3.722 & $0.004^{\mathrm{a}}$ & Men \\
\hline 7.9. Star & 3.831 & 3.775 & 0.291 & No significant difference \\
\hline 7.10. Family & 3.784 & 3.791 & 0.757 & No significant difference \\
\hline 7.11. Place & 3.503 & 3.611 & $0.095^{\mathrm{a}}$ & Men \\
\hline 7.12. Other & 1.208 & 1.525 & 0.253 & No significant difference \\
\hline 8.1. Recreation, sport & 2.027 & 2.268 & $0.004^{\mathrm{a}}$ & Men \\
\hline 8.2. Nature & 2.044 & 2.095 & 0.505 & No significant difference \\
\hline 8.3. Entertainment & 2.267 & 2.431 & $0.041^{\mathrm{a}}$ & Men \\
\hline 8.4. Culture & 2.469 & 2.390 & 0.276 & No significant difference \\
\hline 8.5. Parties & 2.723 & 2.490 & $0.001^{\mathrm{a}}$ & women \\
\hline 8.6. Other & 1.471 & 1.219 & 0.514 & No significant difference \\
\hline
\end{tabular}

a $p$ calculated for Wilcoxon's test of mean differences, significant when $p<0.05$

Source: author using the SAS package.

Table 13. Assessment of significant differences in relation to origin of respondents

\begin{tabular}{|l|c|c|c|c|}
\hline \multirow{2}{*}{ Variable } & \multicolumn{3}{|c|}{ Differentiation based on origin } \\
\cline { 2 - 4 } & $\begin{array}{c}\text { Mean for fan } \\
\text { from PL }\end{array}$ & $\begin{array}{c}\text { Mean for fan } \\
\text { from abroad }\end{array}$ & $p^{\text {a }}$ & $\begin{array}{c}\text { Interpretation } \\
\text { Barrier/factor more important for }\end{array}$ \\
\hline 3.1. Date & 2.292 & 2.237 & 0.803 & No significant difference \\
\hline 3.2. Cost & 3.084 & 2.297 & $2.9500759 \mathrm{E}-8$ & Polish fan \\
\hline 3.3. Safety & 1.502 & 2.022 & 0.001 & Fan from abroad \\
\hline 3.4. Promotion & 2.001 & 2.356 & 0.012 & Polish fan \\
\hline 3.5. Acquisition & 2.828 & 2.215 & 0.000066 & No significant difference \\
\hline 3.6. Offer & 2.201 & 2.131 & 0.695 & No significant difference \\
\hline 3.7. Time & 2.796 & 2.848 & 0.958 & No significant difference \\
\hline 3.8. Otherence \\
\hline 7.1. Type & 1.329 & 1.560 & 0.376 & Polish fan \\
\hline 7.2. Rivalry & 3.890 & 3.914 & 0.241 & Polish fan \\
\hline 7.3. Brand & 3.899 & 3.620 & 0.0006 & Polish fan \\
\hline 7.4. Relax & 3.684 & 3.146 & $2.7934413 \mathrm{E}-8$ & $4.078027 \mathrm{E}-12$ \\
\hline
\end{tabular}




\begin{tabular}{|l|c|c|c|c|}
\hline \multirow{2}{*}{ Variable } & \multicolumn{2}{|c|}{ Differentiation based on origin } \\
\cline { 2 - 4 } & $\begin{array}{c}\text { Mean for fan } \\
\text { from PL }\end{array}$ & $\begin{array}{c}\text { Mean for fan } \\
\text { from abroad }\end{array}$ & $p^{\text {a }}$ & $\begin{array}{c}\text { Interpretation } \\
\text { Barrier/factor more important for }\end{array}$ \\
\hline 7.5. Live & 4.169 & 3.827 & 0.00002 & Polish fan \\
\hline 7.6. Prestige & 2.977 & 3.095 & 0.985 & Polish fan \\
\hline 7.7. Stake & 3.336 & 2.971 & 0.001 & Polish fan \\
\hline 7.8. Level & 3.674 & 3.228 & $1.0761468 \mathrm{E}-6$ & Polish fan \\
\hline 7.9. Star & 3.845 & 3.343 & $3.246329 \mathrm{E}-7$ & Polish fan \\
\hline 7.10. Family & 3.811 & 3.543 & 0.003 & Polish fan \\
\hline 7.11. Place & 3.582 & 3.292 & 0.012 & Fan from abroad \\
\hline 7.12. Other & 1.392 & 1.684 & 0.668 & Fan from abroad \\
\hline 8.1. Recreation, sport & 2.128 & 2.534 & 0.006 & No significant difference \\
\hline 8.2. Nature & 2.019 & 2.584 & 0.00002 & Fan from abroad \\
\hline 8.3. Entertainment & 2.341 & 2.504 & 0.231 & No significant difference \\
\hline 8.4. Culture & 2.364 & 3.007 & $2.4180173 \mathrm{E}-6$ & 0.794 \\
\hline 8.5. Parties & 2.592 & 2.580 & 0.242 & significant difference \\
\hline 8.6. Other & 1.283 & 1.789 & & \\
\hline
\end{tabular}

a $p$ calculated for Wilcoxon's test of mean differences, significant when $p<0.05$

Source: author using the SAS package.

Among the barriers, Polish fans were more aware of the problem of the cost of a trip to a sports event (trip + ticket). For foreign visitors the sense of security and appropriate promotion of the event were more important.

In terms of factors, Polish fans considered virtually all the factors examined in the research as more important than foreign fans. Only in the area of access to additional recreational, sports and cultural offer did foreign fans indicate higher importance.

\section{RESULTS - ANALYSIS OF CORRELATIONS OF THE ANALYSED VARIABLES}

Using the one-dimensional correlation analysis, significant correlations within the data set were analyzed. Relations with a correlation coefficient greater than 0.2 or less than -0.2 were interpreted (see Table 14).

Within demographic variables, detected relationships are intuitive and confirm obvious patterns present in society. The age of the respondents correlates positively with the such features as income of respondents, professional status and education level. A higher level of education positively correlates with having employment. Professional status is related to age, education and income of the respondents.

An interesting positive relationship exists between income level and the importance of the 'inconvenient match date' barrier (0.205) as well as between the age of the respondents and the importance of the 'lack of free time' barrier (0.202).

\section{RESULTS - EXPLORATORY FACTOR ANALYSIS OF THE DATA SET}

Exploratory factor analysis was used to identify multidimensional relationships between individual variables (importance of barriers, factors and additional factors in tourism) of the model describing the 'predisposition of the respondents to attend sports events'.

The input data set meets the necessary prerequisites for factorial analysis methodology. The sample in the data set is larger than the minimum recommended in the literature, which is 100 (Barret, Kline, 1981, in: Zakrzewska,

Table 14. Correlation detected with a Rho Spearman coefficient less than -0.2 or greater than 0.2 at a significance level of 0.05

\begin{tabular}{|c|c|c|c|c|c|c|c|}
\hline & Age & Education & Employed & Income pl & Income euro & 3.1. date & 3.7. time \\
\hline Age & 1 & 0.315 & 0.382 & 0.472 & 0.399 & & 0.202 \\
\hline Education & & 1 & 0.262 & & & & \\
\hline Employed & & & 1 & 0.235 & & & \\
\hline Income pl & & & & 1 & & & \\
\hline Income euro & & & & & 1 & 0.205 & \\
\hline 3.1.Date & & & & & & 1 & \\
\hline 3.7. Time & & & & & & & 1 \\
\hline
\end{tabular}

Source: author using the SAS package. 
1994) or 200 (Comrey, 1978, in: Zakrzewska, 1994). Cronbach's alpha coefficient at a high level (0.824) indicates the reliability of the scale used. The KMO measure shows a level indicating that correlations between pairs of variables can be explained by other variables (MSA = 0.85709256). ${ }^{4}$ Bartlett's test (Table 15) result suggests that one can reject the hypothesis that the correlation matrix is a unit matrix at a significance level of less than 0.05 , which means that variables are not independent from each other and there are common factors in the data set (Zakrzewska, 1994).

Table 15. Value of coefficients in Bartlett's sphericity test

\begin{tabular}{|l|c|c|c|}
\hline \multirow{2}{*}{} & \multicolumn{3}{|c|}{ Bartlett's sphericity test } \\
\cline { 2 - 4 } & Chi square & Degrees of freedom & $p$ value \\
\hline 1 & 8869.850 & 253 & 0.0000 \\
\hline
\end{tabular}

Source: author using the STATISTICA package.

In the analysis, five common factors were obtained with a value greater than one with 16 input variables (5/16), which meets the criterion of Kaiser concerning the number of common factors necessary and sufficient to explain the interrelationship within the group of variables. ${ }^{5}$

Due to the excessive number of distinguished components that would explain $75 \%$ of the variance recommended in the literature (Zakrzewska, 1994), in order to avoid interpretation problems of the factorial structure, the criterion of $50 \%$ variance was applied and five common factors were distinguished (Table 16). The distinguishing of five common factors is justified by the scree test for the eigenvalues characterizing the individual com-

Table 16. Eigenvalues of the correlation matrix

\begin{tabular}{|c|c|c|c|c|}
\hline \multirow[t]{2}{*}{ Components } & \multicolumn{4}{|c|}{$\begin{array}{l}\text { Correlation matrix eigenvalues: } \\
\text { total }=23, \text { mean }=1\end{array}$} \\
\hline & \begin{tabular}{|l|} 
Eigenvalue \\
\end{tabular} & Difference & Share & Cumulative \\
\hline 1 & 4.897 & 2.442 & 0.213 & 0.213 \\
\hline 2 & 2.455 & 0.389 & 0.107 & 0.320 \\
\hline 3 & 2.066 & 0.815 & 0.090 & 0.410 \\
\hline 4 & 1.251 & 0.225 & 0.054 & 0.464 \\
\hline 5 & 1.026 & 0.060 & 0.045 & 0.509 \\
\hline 6 & 0.966 & 0.110 & 0.042 & 0.551 \\
\hline 7 & 0.856 & 0.039 & 0.037 & 0.588 \\
\hline 8 & 0.817 & 0.010 & 0.036 & 0.623 \\
\hline 9 & 0.807 & 0.060 & 0.035 & 0.658 \\
\hline 10 & 0.746 & 0.028 & 0.032 & 0.691 \\
\hline$(\ldots)$ & $\ldots$ & $\ldots$ & $\ldots$ & $\ldots$ \\
\hline 23 & 0.312 & & 0.014 & 1.000 \\
\hline
\end{tabular}

Source: author using the SAS package. ponents (Figure 1). With a certain degree of caution, they can be used to deduce from the population surveyed.

In the analysis of the saturation of the distinguished factors by particular raw variables (Table 17), the values of loadings higher than or very close to 0.5 were treated as significant (Zakrzewska, 1994).

The obtained common factors were interpreted and ordered from the most to the least differentiating group (Table 18). A five-element factorial model determining the motivation of the respondents to participate in sports events was achieved.
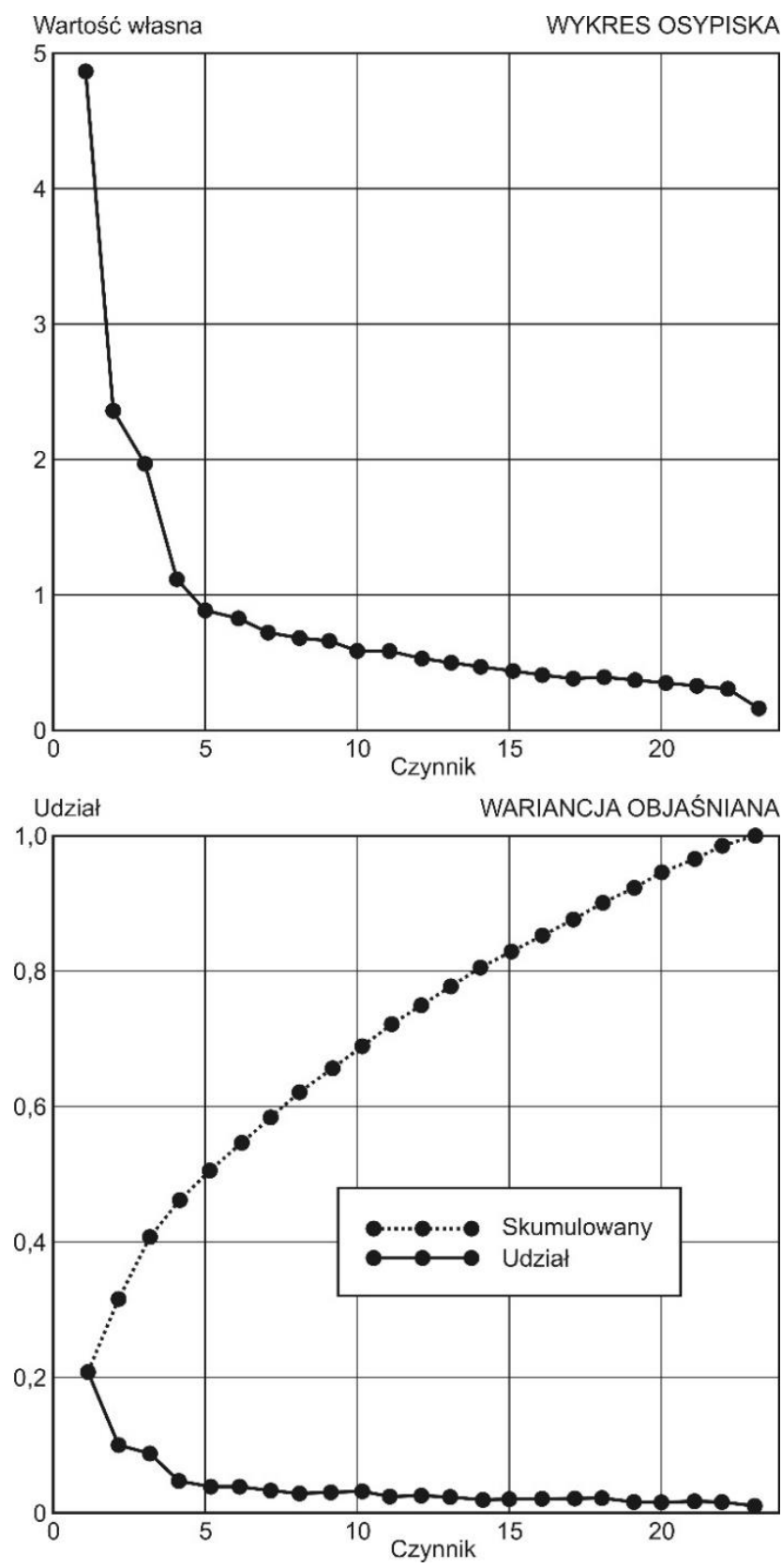

Figure 1. Scree test Source: author using the SAS package 
Table 17. Factor loadings: system of factors rotated using the 'orthogonal varimax' method [bold values of correlation coefficients greater or very close to 0.5 ]

\begin{tabular}{|l|c|c|c|c|c|}
\cline { 2 - 5 } \multicolumn{1}{c|}{} & Factor 1 & Factor 2 & Factor 3 & Factor 4 & Factor 5 \\
\hline stnd_8.2. Nature & $\mathbf{0 . 7 9 7}$ & 0.170 & 0.078 & 0.037 & -0.016 \\
\hline stnd_8.4. Culture & $\mathbf{0 . 7 8 2}$ & 0.067 & 0.087 & 0.170 & -0.118 \\
\hline stnd_8.5. Parties & $\mathbf{0 . 7 7 5}$ & 0.095 & 0.046 & 0.129 & 0.045 \\
\hline stnd_8.3. Entertainment & $\mathbf{0 . 7 3 6}$ & 0.105 & 0.040 & 0.026 & 0.154 \\
\hline stnd_8.1. Recreation, sport & $\mathbf{0 . 6 4 5}$ & 0.164 & 0.016 & -0.007 & 0.223 \\
\hline stnd_3.3. Safety & 0.135 & $\mathbf{0 . 7 1 0}$ & -0.013 & 0.039 & 0.153 \\
\hline stnd_3.4. Promotion & 0.149 & $\mathbf{0 . 6 8 2}$ & 0.014 & -0.021 & 0.088 \\
\hline stnd_3.6. Offer & 0.182 & $\mathbf{0 . 6 6 5}$ & 0.046 & -0.019 & 0.249 \\
\hline stnd_3.1.Date & 0.132 & $\mathbf{0 . 6 5 0}$ & 0.173 & -0.036 & -0.005 \\
\hline stnd_3.7. Ttime & -0.018 & $\mathbf{0 . 5 8 2}$ & 0.205 & 0.024 & -0.201 \\
\hline stnd_3.2. Cost & 0.080 & $\mathbf{0 . 5 3 8}$ & 0.041 & 0.153 & -0.145 \\
\hline stnd_3.5. Acquisition & 0.013 & $\mathbf{0 . 4 9 6}$ & 0.058 & 0.032 & 0.280 \\
\hline stnd_7.1. Type & 0.077 & 0.079 & $\mathbf{0 . 7 3 2}$ & 0.056 & 0.008 \\
\hline stnd_7.3. Brand & 0.005 & 0.124 & $\mathbf{0 . 6 8 3}$ & 0.064 & 0.102 \\
\hline stnd_7.2. Rivalry & 0.054 & 0.034 & $\mathbf{0 . 6 6 1}$ & 0.233 & -0.040 \\
\hline stnd_7.8. Level & 0.024 & 0.040 & $\mathbf{0 . 6 2 6}$ & 0.083 & 0.300 \\
\hline stnd_7.7. Stake & 0.050 & 0.115 & $\mathbf{0 . 5 7 0}$ & -0.030 & 0.442 \\
\hline stnd_7.11. Place & 0.124 & 0.169 & 0.363 & 0.290 & -0.083 \\
\hline stnd_7.4. Relax & 0.081 & 0.100 & 0.130 & $\mathbf{0 . 7 1 0}$ & 0.036 \\
\hline stnd_7.5. Live & 0.028 & -0.116 & 0.140 & $\mathbf{0 . 7 0 4}$ & 0.058 \\
\hline stnd_7.10. Family & 0.131 & 0.101 & 0.077 & $\mathbf{0 . 6 8 4}$ & 0.206 \\
\hline stnd_7.6. Prestige & 0.152 & 0.174 & 0.132 & 0.164 & $\mathbf{0 . 7 0 0}$ \\
\hline stnd_7.9. Star & 0.093 & -0.036 & 0.329 & 0.323 & $\mathbf{0 . 4 9 4}$ \\
\hline
\end{tabular}

Source: author using the SAS package.

Table 18. Interpretation of the layout of common factors

\begin{tabular}{|c|c|c|c|}
\hline Factor & Items in the Factor & Decription & Interpretation \\
\hline 1 & $\begin{array}{l}\text { 8.1. Rekreacja, sport } \\
\text { 8.2. Przyroda } \\
\text { 8.3. Rozrywka } \\
\text { 8.4. Kultura } \\
\text { 8.5. Imprezy }\end{array}$ & $\begin{array}{l}\text { Physical recreation, sport } \\
\text { Natural attractions } \\
\text { Entertainment offer } \\
\text { Cultural attractions } \\
\text { Additional events }\end{array}$ & $\begin{array}{l}\text { Availability of additional services } \\
\text { (tourist attractions) accompanying } \\
\text { the event }\end{array}$ \\
\hline 2 & $\begin{array}{l}\text { 3.1. Termin } \\
\text { 3.2. Koszty } \\
\text { 3.3. Bhp } \\
\text { 3.4. Promocja } \\
\text { 3.5. Zakup } \\
\text { 3.6. Oferta } \\
\text { 3.7. Czas }\end{array}$ & $\begin{array}{l}\text { The match timeframe constrains fans } \\
\text { Travel expenses for volleyball matches } \\
\text { Safety concerns during travel and match } \\
\text { Inappropriate promotion of national team matches } \\
\text { Buying tickets for matches } \\
\text { Offer at the matches alone } \\
\text { Lack of free time }\end{array}$ & Barriers \\
\hline 3 & $\begin{array}{l}\text { 7.1. Rodzaj } \\
\text { 7.2. Walka } \\
\text { 7.3. Marka } \\
\text { 7.7. Stawka } \\
\text { 7.8. Poziom }\end{array}$ & $\begin{array}{l}\text { Type of competition (e.g. European Championship) } \\
\text { Possibility of a close-knit sports match } \\
\text { Brand (fame) of rival teams } \\
\text { Match stake } \\
\text { Anticipated sports level }\end{array}$ & $\begin{array}{l}\text { Attractiveness of a sporting event } \\
\text { in terms of its sport level }\end{array}$ \\
\hline 4 & $\begin{array}{l}\text { 7.4. Relax } \\
\text { 7.5. Na żywo } \\
\text { 7.10. Rodzina }\end{array}$ & $\begin{array}{l}\text { Relaxation, entertainment } \\
\text { The willingness to watch the match live } \\
\text { Opportunity to go to a match with beloved ones }\end{array}$ & $\begin{array}{l}\text { Recreational function of the show } \\
\text { - free time spent with the family } \\
\text { in an attractive way }\end{array}$ \\
\hline 5 & $\begin{array}{l}\text { 7.6. Prestiż } \\
\text { 7.9. Gwiazda }\end{array}$ & $\begin{array}{l}\text { Prestige of being a fan of the national team } \\
\text { Live view of a volleyball star }\end{array}$ & $\begin{array}{l}\text { Prestige - feeling the prestige of an } \\
\text { event }\end{array}$ \\
\hline
\end{tabular}

Source: author. 


\section{CONCLUSION}

On the basis of the presented research results it is possible to check the verification of the hypotheses formulated in the research process (Table 19).

The conclusions of the verification of the hypotheses can be considered as the theoretical contribution. It can be compared to the results obtained by authors using the MSSC scale (Table 20).

The comparison of the obtained results with selected cases using the popular MSSC scale or its modification shows several similarities. The high position of the motives of Dramaturgy and Achievements, as well as the position of family motives seem to be consistent with other studies. The escape motive is always visible in the middle. The place of social meetings in the hierarchy, which can be both at the end and at the beginning, is unclear. Differences in the obtained results may be caused by differences between the studied groups, as well as on the applied research scale.

The obtained five factor model of attendance in sports events is also a contribution to the theory (Fig. 2, Table 18).

Due to the reliability merits of the model obtained, the measurement scale used in the research questionnaire may be considered an alternative way of analysing the willingness to attend major sports events. In comparison to the approaches already used in Poland and abroad for fan research, one should pay attention to the innovation in the construction of this scale. This approach is an attempt to combine a classic set of factors used to study the motivation of fans - Funk, Filo, Beaton, Pritchard (2009); Kim, Trail (2010); Milne, McDonald (1999), in: Won, Kitamura (2007); Neale, Funk (2006); Sloan (1989); Trail, James (2001); Wann (1999),

Table 19. Verification of hypotheses

\begin{tabular}{|l|l|}
\hline Hypothesis & \multicolumn{1}{c|}{ Verification of hypotheses } \\
\hline 1 & $\begin{array}{l}\text { Significant differences in the perception of importance of particular barriers/factors were identified between } \\
\text { women and men, as well as between Polish fans and foreigners (Tables 11,12). }\end{array}$ \\
\hline 2 & $\begin{array}{l}\text { Average assessments of the importance of individual factors differ, which makes it possible to create lists of } \\
\text { factors ordered by importance (Tables 6, 8, 10). }\end{array}$ \\
\hline 3 & $\begin{array}{l}\text { The assessment of the importance of attendance factors in sports events is partly correlated with the variables } \\
\text { describing the demographic profile of the respondents (Table 13). }\end{array}$ \\
\hline 4 & The studied barriers and factors allow five hidden factors to be identified (Table 16). \\
\hline
\end{tabular}

Source: author.

Table 20. Comparison of the obtained hierarchy of factors in the author's research with the measured importance of motives on an MSSC scale in selected studies

\begin{tabular}{|c|c|c|c|c|c|c|}
\hline & $\begin{array}{l}\text { Own research } \\
\text { [see also table 8] }\end{array}$ & $\begin{array}{c}\text { MSSC modified } \\
\text { (research results) } \\
\text { N=222 (Ryśnik, } \\
\text { Żylak, Tomik, } \\
\text { 2018) }\end{array}$ & $\begin{array}{l}\text { MSSC Korean } \\
\text { fans } N=511 \\
\text { (Won, } \\
\text { Kitamura 2007) }\end{array}$ & $\begin{array}{c}\text { MSSC Japan } \\
\text { jans; N=593 } \\
\text { (Won, } \\
\text { Kitamura, 2007) }\end{array}$ & $\begin{array}{l}\text { MSSC (when } \\
\text { the favorite } \\
\text { player is play- } \\
\text { ing) } N=142 \\
\text { (Fink, Parker, } \\
\text { 2009) }\end{array}$ & $\begin{array}{c}\text { MSSC (when } \\
\text { the favorite } \\
\text { player is not } \\
\text { playing) N=142 } \\
\text { (Fink, Parker, } \\
\text { 2009) }\end{array}$ \\
\hline \begin{tabular}{|l} 
Factors \\
in order \\
of importance \\
(measured \\
average \\
value \\
of factors or \\
subscale)
\end{tabular} & $\begin{array}{l}\text { 1. The willingness to } \\
\text { watch the match live } \\
\text { 2. Type of competition } \\
\text { (e.g. European Champi- } \\
\text { onship), Possibility of } \\
\text { a close-knit sports fight, } \\
\text { Relaxation, Live view of } \\
\text { a volleyball star, Oppor- } \\
\text { tunity to go to a match } \\
\text { with family } \\
\text { 3. Fame of rival teams } \\
\text { 4. Anticipated sports } \\
\text { level, Place of competi- } \\
\text { tion (match) } \\
\text { 5. Match stake } \\
\text { 6. Prestige of being a fan }\end{array}$ & $\begin{array}{l}\text { 1. Aesthetics, } \\
\text { Drama. } \\
\text { 2. Achievements } \\
\text { and Knowledge } \\
\text { 3. Escape } \\
\text { 4. Social meeting } \\
\text { 5. Family }\end{array}$ & $\begin{array}{l}\text { 1. Drama } \\
\text { 2. Achievements } \\
\text { 3. Entertainment } \\
\text { 4. Escape } \\
\text { 5. Pride in being } \\
\text { in a group } \\
\text { 6. Family } \\
\text { 7. Skills } \\
\text { 8. Social Meet- } \\
\text { ings } \\
\text { 9. Attractiveness } \\
\text { of players }\end{array}$ & $\begin{array}{l}\text { 1. Achievements } \\
\text { 2. Entertainment } \\
\text { 3. Drama } \\
\text { 4. Skills } \\
\text { 5. Escape } \\
\text { 6. Pride in being } \\
\text { in a group } \\
\text { 7. Family } \\
\text { 8. Social } \\
\text { Meetings } \\
\text { 9. Attractiveness } \\
\text { of players }\end{array}$ & $\begin{array}{l}\text { 1. Skills } \\
\text { 2. Drama } \\
\text { 3. Meetings } \\
\text { 4. Achieve- } \\
\text { ments } \\
\text { 5. Escape } \\
\text { 6. Aesthetics } \\
\text { 7. Family } \\
\text { 8. Knowledge } \\
\text { 9. Physical } \\
\text { Attractiveness }\end{array}$ & $\begin{array}{l}\text { 1. Drama } \\
\text { 2. Skills } \\
\text { 3. Meetings } \\
\text { 4. Escape } \\
\text { 5. Aesthetics } \\
\text { 6. Family } \\
\text { 7. Knowledge } \\
\text { 8. Achievements } \\
\text { 9. Physical } \\
\text { Attractiveness }\end{array}$ \\
\hline
\end{tabular}

Source: author's compilation based on the sources in the table. 


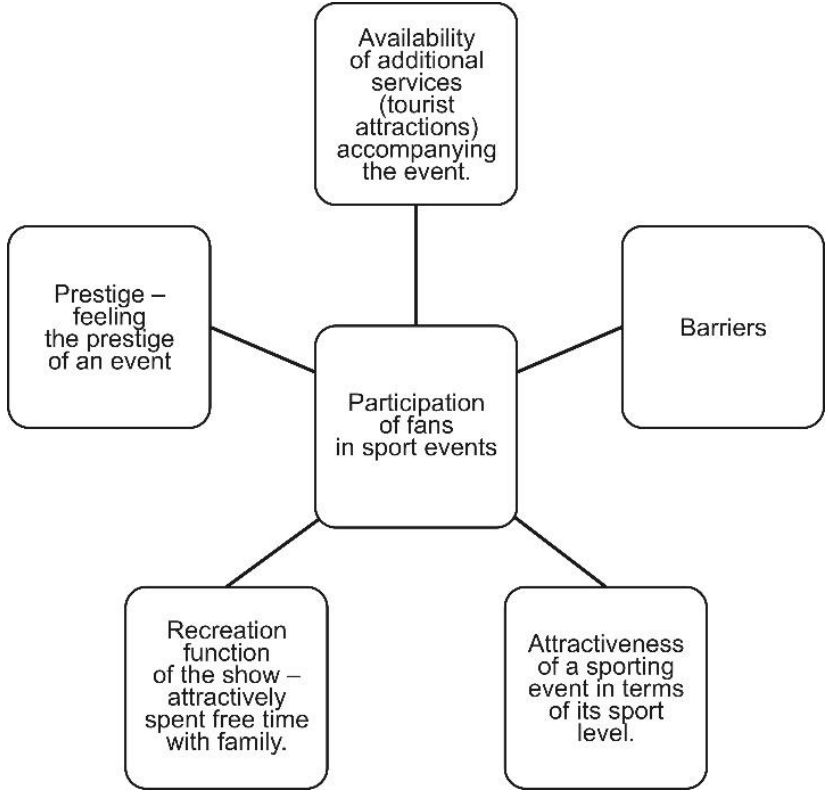

Figure 2. Factors influencing attendance by fans at a sporting event

Source: author

in: Hadzik (2016); with barriers to attendance - Anthony, Kahn, Madison, Paul, Weinbach (2014); Mohan, Thomas (2012); Nishio (2014); Simmons, Popp, McEvoy, Ho- well (2018); Yu (2010); making the author's approach conceptually similar to the synthetic approach used by Kim \& Trail (2010). At the same time it is an attempt to search for a specific 'common space' created at the junction of sports and tourism (Szczechowicz, 2015) by attaching to the model a broader context of the event in the form of entertainment events or tourist products, for instance.

The results obtained confirm that tourism and sport are phenomena that can and should be studied together.

\section{INDICATIONS FOR PRACTITIONERS}

Conclusions from the verification of hypotheses can be considered from the point of view of usefulness for managers of entities responsible for the development of products in sports tourism. A set of postulates was formulated for the management practice of major sporting events in order to meet the preferences of travelling fans (Table 21).

The use of the recommendations and suggestions in Table 19 should foster the attendance of fans in major sporting events.

Table 21. Practical conclusions based on the verification of the hypotheses

\begin{tabular}{|c|c|c|}
\hline Hipotesis & Verification of the hypothesis & Practical conclusions \\
\hline 1 & $\begin{array}{l}\text { Significant differences in the per- } \\
\text { ception of importance of particular } \\
\text { barriers/factors were identified be- } \\
\text { tween women and men, as well as } \\
\text { between Polish fans and foreigners } \\
\text { (Tables 11,12) }\end{array}$ & $\begin{array}{l}\text { The design of the offer and the distribution of accents in the message promoting } \\
\text { the event should be differentiated according to the target group (gender, origin). } \\
\text { 1) The offer and promotional message aimed at men should be more focused } \\
\text { on highlighting: } \\
\text { - the convenience of the dates and accessibility of the venue of the event } \\
\text { - the rank of the event and its sporting level } \\
\text { - availability of additional entertainment events } \\
\text { 2) The offer and promotional message aimed at women should emphasise to } \\
\text { a greater extent: } \\
\text { - the price of the event's attractiveness } \\
\text { - the potential level of relaxation associated with the event } \\
\text { - the prestigious nature of the event } \\
\text { - availability in a package of other additional events involving fans in the } \\
\text { field of physical recreation and sport } \\
\text { 3) The offer and promotion aimed at people from abroad should be particularly } \\
\text { focused on: } \\
\text { - high safety standards at the event } \\
\text { - high quality information about the event } \\
\text { - access to additional services at the venue itself } \\
\text { - easily accessible cultural and natural attractions } \\
\text { 4) The offer and promotion addressing persons in the country should emphasize: } \\
\text { - cost-attractiveness } \\
\text { - sporting level } \\
\text { - watching live, interacting with sports stars } \\
\text { - possibility of relaxation with the family }\end{array}$ \\
\hline 2 & $\begin{array}{l}\text { Average assessments of the im- } \\
\text { portance of individual factors dif- } \\
\text { fer, which makes it possible to cre- } \\
\text { ate lists of factors ordered by } \\
\text { importance - the hierarchy of fac- } \\
\text { tors (Tables } 6,8,10 \text { ) }\end{array}$ & $\begin{array}{l}\text { 1) Taking under consideration the two most important barriers for fans, while } \\
\text { developing the offer and formulating the promotional message it is recom- } \\
\text { mended first of all to focus at reduction the cost and time inconveniences } \\
\text { of attendance in a sport event (Table 9). }\end{array}$ \\
\hline
\end{tabular}


Table 21 (cont.)

\begin{tabular}{|c|c|c|}
\hline Hipotesis & Verification of the hypothesis & Practical conclusions \\
\hline & & $\begin{array}{l}\text { 2) Factors assessed as the most important (Table 11, 13) indicate the need for } \\
\text { special treatment of the following issues: } \\
\text { - the value of watching the event live (authenticity and uniqueness of the } \\
\text { event and the possibility of dealing with celebrities) } \\
\text { - the sporting level of the event } \\
\text { - the qualities contributing to relaxation in the family circle }\end{array}$ \\
\hline 3 & $\begin{array}{l}\text { The assessment of the importance of } \\
\text { attendance factors in sports events is } \\
\text { partly correlated with the variables } \\
\text { describing the demographic profile } \\
\text { of the respondents (Table 13) }\end{array}$ & $\begin{array}{l}\text { Event organisers should be aware of the fact that attracting an older and wealthier } \\
\text { sports fan requires addressing time constraints and the problem of setting a con- } \\
\text { venient date for an event. It is therefore necessary to choose the best time for the target } \\
\text { group or to introduce various time-saving improvements to optimise the use of their } \\
\text { time. }\end{array}$ \\
\hline 4 & $\begin{array}{l}\text { The studied barriers and factors al- } \\
\text { low five hidden factors to be iden- } \\
\text { tified (Table 16) }\end{array}$ & $\begin{array}{l}\text { The derived model is a guideline for managers on the issue of how the individual } \\
\text { characteristics of an event are processed in the perception process of a sport fan. } \\
\text { 1. There is a substitution between the variables making up a given common fac- } \\
\text { tor and therefore they may be treated interchangeably. } \\
\text { 2. However, substitution does not occur between variables forming different } \\
\text { common factors. } \\
\text { Managers should consider separately the efforts/effects of actions aimed at five } \\
\text { different elements of the model (there is no substitution in the range of variables } \\
\text { of different factors). For example, it is not possible to compensate the poor quality of } \\
\text { sport level of the event with the elimination of some barriers. } \\
\text { Managers should make equally strong, parallel efforts in terms of: } \\
\text { - availability of additional services, events, attractions, } \\
\text { - levelling of barriers } \\
\text { - increasing the attractiveness of the sporting event with regard to the sporting } \\
\text { level } \\
\text { - increasing the attractiveness of the spectacle for those who seek relaxation and } \\
\text { pleasant time spent with their families } \\
\text { - building the prestige of fans at a given sporting event and the involvement } \\
\text { of sporting stars in the event }\end{array}$ \\
\hline
\end{tabular}

Source: author.

\section{ENDNOTES}

1 "Tourism demand can be understood as the sum of the services and goods that tourists are willing to purchase at a given price level and over a given period of time" (Niezgoda, Zmyślony, 2006, in: Kachniewska, Nawrocka, Niezgoda, Pawlicz, 2012, p. 31).

2 Some results based on an incomplete sample $(\mathrm{N}=434)$ were published in Hadzik, Ryśnik, Tomik (2015).

${ }^{3}$ Total estimated attendance of fans at matches from phases I, II, III at the "Spodek" arena in Katowice, where research was conducted on the basis of data from the Polish Volleyball Federation (PZPS).

4 "KMO lower than 0.5 - very low (unacceptable)" (Zakrzewska, 1994).

5 This number should be within the range from $1 / 6$ to $1 / 3$ of the total number of examined variables (Zakrzewska,1994).

\section{BIBLIOGRAPHY}

Ahn, S.C., Lee, Y.H. (2014). Major league baseball atten-dance: Longterm analysis using factor models. Journal of Sports Economics, 15 (5), 451-477. DOI: https://doi.org/10.1177/1527002514535171
Anthony, T., Kahn, T., Madison, B., Paul, R., Weinbach, A. (2014). Similarities in fan preferences for minor-league baseball across the American Southeast. Journal of Economics \& Finance, 38 (1), 150-163. DOI: https://doi.org/10.1007/s12197-011-9214-7

Fairley, S. (2009). The role of the mode of transport in the identity maintenance of sport fan travel groups. Journal of Sport $\mathcal{E}$ Tourism, 14 (2/3), 205-222, 2009. DOI: https://doi.org/$10.1080 / 14775080902965231$

Fink, J.S., Parker, H.M. (2009). Spectator motives: why do we watch when our favourite team is not playing? Sport Marketing Quarterly, 18, 210-217.

Fink, J.S., Trail, G.T., Anderson, D.F. (2002). Environmental factors associated with spectator attendance and sport consumption behavior: Gender and team differences. Sport Marketing Quarterly, 11, 8-19.

Funk, D.C., Filo, K., Beaton, A.A., Pritchard M. (2009). Measuring the motives of sport event attendance: Bridging the academicpractitioner divide to understanding behavior. Sport Marketing Quarterly, 18 (3), 126-138.

Hadzik, A. (2014). Turystyka sportowa ze szczególnym uwzględnieniem międzynarodowych widowisk sportowych. Katowice: Akademia Wychowania Fizycznego w Katowicach.

Hadzik, A. (2016). Uwarunkowania rekreacyjnego uczestnictwa w sporcie kibiców międzynarodowych widowisk sportowych. Kraków: European Association For Security.

Hadzik, A., Bartík, P. (2012). The chosen factors of attending in international sports events on the example of football, basketball and volleyball games in Poland. Exercitatio Corpolis-motus-salus. Slovak Journal of Sport Sciences, 1 (4), 141-149. 
Hadzik, A., Ryśnik, J., Tomik, R. (2015). Determinanty uczestnictwa w międzynarodowych widowiskach sportowych: w świetle wyników badań. Prace Naukowe Uniwersytetu Ekonomicznego we Wrocławiu, 379, 75-86. DOI: https://doi.org/10.15611/pn.2015.379.07

Kachniewska, M., Nawrocka, E., Niezgoda, A., Pawlicz, A. (2012). Rynek turystyczny, ekonomiczne zagadnienia turystyki. Warszawa: Wolters Kluwer Polska Sp. z o.o.

Kaczmarek, J., Stasiak, A., Włodarczyk, B. (2010). Produkt turystyczny. Pomyst, organizacja, zarzadzanie. Warszawa: Polskie Wydawnictwo Ekonomiczne.

Kazimierczak, M., Malchrowicz-Mośko, E. (2013). Turystyka sportowa - specyfika i trendy rozwojowe. Folia Turistica, 28 (1), 67-90.

Kemper, C., Breuer, C. (2015). What factors determine the fans' willingness to pay for Bundesliga tickets? An analysis of ticket sales in the secondary market using data from ebay.de. Sport Marketing Quarterly, 24 (3), 142-158.

Kim, Y.K., Trail, G.T. (2010). Constraints and motivators: A new model to explain sport consumer behavior. Journal of Sport Management, 24, 190-210. DOI: https://doi.org/10.1123/jsm.24.2.190

Klisiński, J. (2011). Rynek dóbr i ustug sportowych. Bielsko-Biała: Wydawnictwo Naukowe ATH.

Kramer, J. (1997). Konsumpcja w gospodarce rynkowej. Warszawa: PWE.

Kruger, M., Saayman, M. (2012). Why do fans attend world wrestling entertainment? South African Journal for Research in Sport, Physical Education \& Recreation, 34 (2), 63-81.

Milne, G.R., McDonald, M.A. (1999). Sport marketing: managing the exchange process. Sudbury, MA: Jones and Bartlett Publishers.

Mohan, L., Thomas, L. (2012). The impact of distance on fans' intentions to attend team sporting events: A case study of fans of the Carolina Hurricanes of the United States National Hockey League. Annals of Leisure Research, 15 (3), 296-309. DOI: https://doi.org/10.1080/11745398.2012.693041

Neale, L., Funk, D., (2006). Investigating motivation, attitudinal loyalty and attendance behaviour with fans of Australian Football. International Journal of Sports Marketing \& Sponsorship, 7 (4), 307-317.

Nishio, T. (2014). The constraint factors of potential international sports fan tourists. Journal of Vacation Marketing, 20 (2), 137-147. DOI: https://doi.org/10.1177/1356766713496420

Pilarczyk, B., Mruk, H. (2006). Kompendium wiedzy o marketingu. Warszawa: PWN.

Pitts, B.G., Stotlar, D.K. (2002). Fundamentals of sport marketing. Morgantown: Fitness Information Technology.

Robinson, M., Trail, G.T. (2005). Relationships among spectator gender, motives and points of attachment in selected intercollegiate sports. Journal of Sport Management, 19, 58-80. DOI: https://doi.org/10.1123/jsm.19.1.58

Ryśnik, J., Żylak, D., Tomik, R. (2018). Propozycja skali pomiarowej motywacji kibiców do konsumpcji turystyki sportowej. Raport z badań pilotażowych. Folia Turistica, 48, 87-116. DOI: https://doi.org/10.5604/01.3001.0012.7693

Shapiro, S.L., Drayer, J. (2014). An examination of dynamic ticket pricing and secondary market price determinants in Major League Baseball. Sport Management Review, 17, 145-159.

Simmons, J.M., Popp, N.K., McEvoy, C.D., Howell, S.M. (2018). Using fan passion to investigate constraints to student attendance at college football games. Journal of Intercollegiate Sport, 11 (2), 193-213.
Sloan, L.R. (1989). The motives of sports fans. In: J.H. Goldstein (ed.), Sports, games, and play: social \& psychological viewpoints (pp. 175-240). $2^{\text {nd }}$ edition. Hillsdale, NJ: Lawrence Erlbaum Associates.

Smith, A.C.T., Stewart, B. (2007). The travelling fan: understanding the mechanisms of sport fan consumption in a sport tourism setting. Journal of Sport \& Tourism, 12 (3-4), 155-181. DOI: https://doi.org/10.1080/14775080701736924

Standeven, J., De Knop, P. (1999). Sport tourism. Champaign: Human Kinetics.

Steczkowski, J. (1995). Metoda reprezentacyjna w badaniach zjawisk ekonomiczno-społecznych. Warszawa: Wydawnictwo Naukowe PWN.

Surdam, D.G. (2009). What brings fans to the ball park? Evidence from New York Yankees' and Philadelphia Phillies' financial records. Journal of Economics, 35 (1), 35-47.

Szczechowicz, B. (2015). Łączenie wartości turystyki i sportu w świetle analizy ofert rynkowych. In: M. Kazimierczak (ed.), Turystyka sportowa. Spoteczno-kulturowy potencjat i perspektywy rozwoju (pp. 41-54). Poznań: Wydawnictwo Akademii Wychowania Fizycznego.

Trail, G.T., James, J.D. (2001). The motivation scale for sport consumption: Assessment of the scale's psychometric properties. Journal of Sport Behavior, 24 (1), 108-127.

Trail, G.T., Anderson, D.F., Fink, J.S. (2002). Examination of gender differences in importance and satisfaction with venue factors at intercollegiate basketball games: Effects on future spectator attendance. International Sports Journal, 6, 51-64.

Trail, G.T., Fink, J.S., Anderson, D.F. (2003). Sport spectator consumption behavior. Sport Marketing Quarterly, 12, 8-17.

Wann, D.L., Schrader, M.P., Wilson, A.M. (1999). Sport fan motivation: questionairre validation, comparison by sport, and relationship to athletic motivation. Journal of Sport Behaviour, 22 (1), 114-139.

Weed, M., Bull, C. (2004). Sports tourism: participants, policy and providers. Oxford: Elsevier.

Wojdakowski, P. (2008). Bariery uczestnictwa turystów sportowych w meczach piłki nożnej. In: W.W. Gaworecki, Z. Mroczyński, Turystyka $i$ sport dla wszystkich $w$ promocji zdrowego stylu życia (pp. 435-445). Gdańsk: Wyższa Szkoła Turystyki i Hotelarstwa w Gdańsku.

Wojdakowski, P. (2011). Determinanty uczestnictwa turystów sportowych w meczach pitki nożnej. Phd thesis. Częstochowa: Politechnika Częstochowska.

Won, J., Kitamura, K. (2007). Comparative analysis of sport consumer motivations between South Korea and Japan. Sport Marketing Quarterly, 16, 93-105.

Yu, C.-C. (2010). Factors that influence international fans' intention to travel to the United States for sport tourism. Journal of Sport \& Tourism, 15 (2), 111-137. DOI: https://doi.org/10.1080/14775085.2010.498249

Zakrzewska, M. (1994). Analiza czynnikowa w budowaniu $i$ sprawdzaniu modeli psychologicznych. Poznań: Wydawnictwo Naukowe UAM.
Article received:

12 May 2019

Accepted:

23 June 2019 
